\title{
Features of the Use of Modern Technology and Hardware at the Institute of Prosecution with the Aim of Prospering the Higher Education
}

\author{
Igor O. Antonov ${ }^{1}$, Ramil R. Rakhmatullin ${ }^{1}$, Guzel V. Burganova ${ }^{1} \&$ Nikita N. Makolkin ${ }^{1}$ \\ ${ }^{1}$ Department of law, Kazan Federal University, Kazan, Russia. \\ Correspondence: Nikita N. Makolkin, Kazan (Volga region) Federal University, 420111, p/o box 627, for Lukin \\ Yu.M, Kazan, Russia. E-mail: nikita.makolkin@gmail.com
}

Received: July 31, 2019

Accepted: December 7, 2019

Online Published: December 23, 2019

doi:10.5430/ijhe.v8n8p39

URL: https://doi.org/10.5430/ijhe.v8n8p39

\begin{abstract}
In this article, the authors, identifying the features of the use of modern technologies and technical means at the prosecution institute, as a novel strategy emphasize that the principles and rules for the use of modern technologies and technical means in criminal proceedings should fully comply with the purpose of promoting the higher education. Otherwise, as the result the use of modern technologies and technical means in the course of investigative actions will be unlawful, and the evidence obtained in this case will not have legal force for the subsequent trial. From the author's point of view, the approach to the formulation of the principles of promoting higher education in modern science education has not been definitively determined. The discussion on this issue in Russian legal literature and practice has never stopped, which in conclusion indicates the urgency of both this study and the issue as a whole for the functioning and development of higher education inextricably linked with generally recognized principles and norms of international law.
\end{abstract}

Keywords: modern technologies, technical means, principles of the higher education

\section{Introduction}

Technological advancements have caused major changes in policing in the past several decades. Compared to past generations, officers today are surrounded by technology that is intended to increase productivity, officer safety, and agency efficiency.

Communication, for example, has been dramatically improved. The days of communicating with dispatch only through the traditional police radio or tracking down a pay phone to call the station are long gone. Today, officers have cell phones and are responsible for monitoring communications through advanced police radios that can scan many channels or districts at one time. Police vehicles are also equipped with advanced computer-aided dispatch systems. These dispatch systems improve how quickly officers respond to calls for service, assist in the collection of investigative data, and clear calls without radio communication. The evolution of technology directly affects the way the criminal justice system operates at fundamental levels (Siegel, \& Worrall, 2018; Farley, 2019). A wide range of technologies are employed in support of the justice system, including telephony, database management software, computers, automobiles, and weapons. The adoption and implementation of technology also directly shapes the policies and practices of the justice system. For example, the development of modern communications and transportation technologies in the early 1900s increased the response capability of police and changed citizen calls for service. Computers and cellular technologies have increased the capacity of data processing, information sharing, and communications within and across agencies. The increasing societal dependence on the Internet and computer-mediated communications have led law enforcement to develop tools to investigate offenses online. Thus, technology plays a pivotal role in the justice system, though a majority of researchers focus on the implementation and effect of technologies in law enforcement agencies. Like nearly every other industry, the criminal justice field is changing rapidly due to the lightning-fast evolution of technology (Tonry, 2015; Neubauer \& Fradella, 2018).

In modern criminal procedure theory, there are several opinions about the system of principles of the criminal process, their number and classification. For example, Bykov (1994) names fourteen principles of criminal proceedings, Lupinskaya (1971) twenty, Tertyshnik and Shcherba (2011) thirty-one. In addition to quantitative differences in the system of principles of the criminal process, there are also multivariate methods for their classification, which, in our opinion, can be described as single-level and two-level. 
A single-level classification is a simple listing of the principles of the criminal process identified by the author. This classification is used by the overwhelming majority of the learned processors known to us. A two-level supplement to the primary classification of the principles of the criminal process also by the source of origin. Such an approach to the system of principles of the criminal process can be found in the works of Lupinskaya (1971), which proposes to distinguish three groups of principles of criminal proceedings:

1) principles of the criminal process, the source of which are the rights and freedoms of man and citizen;

2) principles of criminal procedure, the source of which are the provisions of the Constitution on the judiciary;

3) proper procedural principles, enshrined only in the norms of the CPC (Lupinskaya, 1971).

In the works of Tertyshnik and Shcherba (2011) the principles of criminal procedure are divided into General legal, intersectoral, sectoral.

Thus, the principles of the criminal process constitute an integrated, logically and structurally related system, which cannot be determined by simply listing them. Therefore, it is preferable that the system of fundamental principles of criminal proceedings, based on a multi-level classification, because it allows you to highlight not only the principles of criminal proceedings, but also the sources (Brown, 2015).

\section{Methods}

Comparative legal and historical methods are chosen as the main methods of research of the considered questions.

The system of principles of the criminal process is the basis for the classification of the principles of using modern technologies and technical means in the criminal process. However, not all principles of the criminal process can be directly related to the use of modern means in criminal proceedings. In this regard, only those that are directly related to the specifics of using modern means in the field of criminal proceedings are selected from all principles (Cole, Smith, \& DeJong, 2018). When formulating the system of principles for applying modern technologies and technical means in criminal proceedings, the group of "applied principles" that characterize the technical means themselves was also taken into account. According to Obraztsov (1997) these principles include:

- legitimacy;

- $\quad$ scientific evidence;

- security;

- $\quad$ rationality and productivity;

- $\quad$ compliance with the established procedure and conditions of use, fixing the course and results of use.

It is thought that the system of principles for applying modern technologies and technical means in criminal proceedings can be represented in the form of three groups:

1. General legal principles in the field of human and civil rights and freedoms, which are generally recognized;

2. Criminal procedure, enshrined in the criminal procedure legislation and defining the features and procedure for the application of modern technologies and technical means;

3. Applied, determining the legality and validity of the use of a particular technical tool in each case.

The general legal principles for the application of modern technologies and technical means in criminal proceedings are:

1) legality;

2) protection of the honor and dignity of the individual;

3) inviolability of the person;

4) inviolability of the home;

5) privacy;

6) presumption of innocence.

All of these general legal principles are also principles of criminal proceedings. Nevertheless, the source of their origin is the Constitution of the Russian Federation, and not the Code of Criminal Procedure of the Russian Federation, therefore, it seems to us that they should be positioned precisely as general legal principles relating to the criminal process, and not just as criminal procedure in essence and content. 
The criminal procedural principles of the use of modern technologies and technical means can be attributed (Ishin, 2011):

1) protection of the rights and freedoms of man and citizen;

2) publicity;

3) immediacy of the study of evidence obtained using modern technologies and technical means;

4) eligibility of entities using technical means.

Finally, the applied principles of applying modern technologies and technical means:

1) scientific validity;

2) safety;

3) authenticity of the materials received (Dennis, 1995).

We can distinguish the main areas of use of modern technologies and technical means in the framework of investigative actions:

- the use of means of auditory and visual recording of testimony in the production of investigative actions;

- demonstration to the interrogated video and audio recordings of interrogations of suspects and accused, containing evidence incriminating him;

- demonstration to the interrogated of the possibilities of forensic examination and modern technologies and technical means in the study of material evidence in the case (Heydon, 1973).

Thus, any form of application of modern technologies and technical means in the process of criminal proceedings is not only an indirect obstacle to the actions of criminals to counteract the investigation, but also contributes to better consolidation of evidence, giving them clarity and persuasiveness (Mapes, Kloosterman, \& de Poot, 2015).

\section{Results and Discussion}

A technical record of the course of investigative actions allows you to record the maximum number of small parts that are completely impossible to reflect in written records. In addition, the use of modern technologies and technical means prevents a possible violation of procedural rules during the investigation, since it allows you to record its process continuously and fully and, thus, is an additional guarantee of the observance of human and civil rights and freedoms in criminal proceedings. (Maleta \& Stipanovic, 2018)

It is obvious that the variety of forms and methods of applying modern technologies and technical equipment poses a challenge for researchers in this field to classify them. As a rule, in works dealing with the use of modern technologies and technical means, mentions a possible classification of according to various criteria: sources of origin, purpose, and subjects of use. The indicated principles of primary classification are given in the works of Obraztsov (1997).

In our opinion, the classification of modern technologies and technical means used in the disclosure and investigation of crimes can be based on three main criteria, namely, to which we include: 1) sources of origin; 2) purpose; 3) scope (Ryan \& Frater, 2002).

According to the sources of origin, the technical means used in the disclosure and investigation of crimes are divided into two large groups: widespread and special.

Technical means of wide application are used in industry, cultural and scientific fields, in the activities of law enforcement agencies and special services. For example, these are household and professional video equipment, sound recorders, and other technical equipment produced for a significant number of consumers.

The peculiarity of this group of technologies and technical means is that they themselves do not undergo any design changes, the tactics and methods of their application can be not only special, but also vary significantly depending on the stage of criminal proceedings in which the given technical means is used. A typical example here is the means of audio and video recording, the tactics and methods of application of which during the implementation of operational-search measures and court proceedings differ radically, although the technical means themselves can be exactly the same.

Technical means of wide application can perform the functions of special equipment in those cases when the tactics and methods of their use are special. In this case, they are talking about their adaptation to the tasks of solving and investigating crimes, since their design remains unchanged, and the tactics and methods of use become special. 
Technical means of wide application can perform the functions of instrumental and technical support of operational-search measures and investigative actions.

In a special group, technical means of widespread use can be singled out, the design of which was amended in order to give them the properties of special equipment. Such a group of funds can, in our opinion, be positioned as modified. Their main purpose is to perform the functions of operational or other special equipment. Modified equipment is a modified technical means of wide application and differs from mass-produced products by a number of units and parts. As modified modern technologies and technical means, voice recorders, cameras installed in disguise items, etc. are noted.

Special technical means can be characterized as devices and devices specially designed for use in the detection and investigation of crimes, forensic and expert studies, and other areas of law enforcement. Such technical means are so specific that they are not used in other fields of activity or for other purposes. A typical example is hardware designed to tacitly obtain information.

Special technical means are distinguished by their adaptability to solve any specific problems. For example, a specialized camera mounted in a belt buckle is designed to capture information in specific conditions and its use for other purposes is almost impossible.

In some cases, the use of special modern technologies and technical means is carried out in the bodies of inquiry and preliminary investigation not for their direct but close purpose. Such technical means should include a number of instruments and devices that enter the armed forces and are used to investigate and solve crimes without modification, for example, night sights for small arms, mine detectors, etc. These special technical means are adapted, since only the tactics and methods of their use change, while the technical means themselves remain in the initial state.

Adapted technical means can be used at all stages of criminal proceedings, but they were most widely used in operational investigative and investigative activities, as well as in conducting expert studies. The tactics and methods of applying this group of modern technologies and technical means can be both standard and adjusted taking into account the specifics of criminal proceedings.

Technical means, originally made for special use, are distinguished by a specific design specificity. As a rule, they have simpler controls, small dimensions and weight, ease of use. An example of specially made for the operational use of modern technologies and technical means are: secretly wearable portable radio stations, means and systems of secret visual and audio surveillance, devices for removing information from communication channels, etc.

With regard to the tasks of disclosing and investigating crimes, specially created technical means can also be divided into two large groups: operational equipment, which is designed and intended for use in operational investigative activities, and forensic equipment for use in the preliminary investigation, investigation of traces of crimes, conducting expert research and investigative actions. The tactics and methods of applying these modern technologies and technical means are always special and are developed taking into account the narrowness of their field of use.

Types of operational equipment intended for secretly obtaining information are reflected in the list approved by resolution of the Government of the Russian Federation of July 1, 1996 N 770, in which special technical means are indicated for receiving and recording acoustic information, visual observation and documentation, listening to telephone conversations, intercepting and recording information from technical communication channels, penetration and inspection of premises, vehicles and other objects, controlling movement vehicles, obtaining information from modern technologies and technical means of its storage, processing and transmission, personal identification. In the literature, this list is used as the basis for classifying operational equipment, however, only a fraction of the modern technologies and technical equipment listed in it is used by the police officers.

The division of modern technologies and technical means into those having camouflage elements and not having those is characteristic of operational equipment. Camouflage elements of special modern technologies and technical means look like household appliances or common items. In this case, the outer shell is an integral part of the design of the technical means, without which it cannot work. Camouflage is carried out to ensure the open application of modern technologies and technical means in the presence of strangers (Shubin, 2010).

The appearance of modern technologies and technical equipment that does not have camouflage is determined only by the features of their design, so they are used in the absence of outsiders or from shelters. If such use is not possible, technical means are placed inside various container objects or in clothes and personal items. The secretive use of modern technologies and technical equipment of this group makes it necessary to take into account the possibility of their accidental detection. 


\subsection{Summary}

The authors formulated a system of principles for the application of modern technologies and technical means in criminal proceedings within the framework of the institution of prosecution. The main task of applying various technologies and technical means is the formation of evidence by searching, fixing and researching various objects. It is noted that the normative basis for their use is the Code of Criminal Procedure of the Russian Federation. The analysis of the current state of use of scientific and technical means and methods in the activities of the investigator, the organization and tactics of using scientific and technical means and methods of this activity. The suggestions and recommendations contained in the article on improving the use of scientific and technical means and methods in the activities of an investigator in the disclosure and investigation of crimes can be used: in the practical activities of investigative units in carrying out this type of activity; in the process of improving the criminal procedure legislation; in the preparation of teaching materials in the educational process of educational institutions that train investigators (Rakhmatullin, 2018).

\section{Conclusion}

The peculiarity of using modern technologies and technical means at the prosecution institute should be understood as a certain combination of means, methods and methods of collecting (searching, detecting, fixing, seizing), as well as processing and transmitting basic information about the investigated incident to obtain criminal procedural evidence, allowing the process of criminal proceedings to establish the presence or absence of circumstances that are subject to proof, as well as other circumstances that are significant of to investigate specific crimes. An important task of using modern technologies and technical means at the prosecution institution is the organization of the effective functioning of the system of bodies of inquiry and preliminary investigation. Due to the variety of tasks solved with the use of this type of special equipment, its use is carried out by a wide range of subjects and is regulated by a significant number of regulatory acts. A feature of the special equipment of instrumental and technical support for the disclosure and investigation of crimes is the continuous and everyday use of a significant part of its modern technologies and technical means, tactical techniques and methods. The technical means of this group can also be used as auxiliary in carrying out operational-search measures, investigative actions and court proceedings.

\section{Acknowledgment}

The work is performed according to the Russian Government Program of Competitive Growth of Kazan Federal University.

\section{References}

Brown, C. S. (2015). Investigating and prosecuting cyber-crime: Forensic dependencies and barriers to justice. International Journal of Cyber Criminology, 9(1), 55-63.

Bykov, V. M. (1994). The principles of the criminal process under the Constitution of the Russian Federation 1993. Russian justice Journal, 8, 8-9.

Cole, G. F., Smith, C. E. \& DeJong, C. (2018). The American system of criminal justice. Boston: Cengage Learning Publication.

Dennis, I. (1995). The Criminal Justice and Public Order Act. The evidence provisions. The criminal law review, 1 , $1-12$.

Farley, M. A. (2019). Forensic DNA technology. Florida: CRC Press. https://doi.org/10.1201/9781351072120

Heydon, J. D. (1973). Illigally obtained evidence (I). The Criminal Law Review, 1, 604-617.

Ishin, A. M. (2011). Some aspects of the use of information technology during the disclosure and investigation of crimes. Modern problems of information and forensic support of the preliminary investigation and its optimization: international materials. scientific-practical Conf., April 21-22. 2011, 1, 58-72.

Lupinskaya, P. A. (1971). Criminal process: Textbook for high schools. Under the general the editorship of Lupinsky. Moscow: Ugolovo-procedualnoe Law of the Russian Federation Publication.

Maleta, N. \& Stipanovic, I. (2018). Difficulties in procedure of obtaining evidence on money laundering through cryptocurrencies as a possible threat to the market stability. Economic and Social Development: Book of Proceedings, 1, 589-598.

Mapes, A. A., Kloosterman, A. D. \& de Poot, C. J. (2015). DNA in the criminal justice system: the DNA success story in perspective. Journal of forensic sciences, 60(4), 851-856. https://doi.org/10.1111/1556-4029.12779 
Neubauer, D. W. \& Fradella, H. F. (2018). America's courts and the criminal justice system. Boston: Cengage Learning Publication.

Obraztsov V. A. (1997). Criminalistics. Under the editorship of Obraztsov. Moscow: Ugolovo-procedualnoe Law of the Russian Federation Publication.

Rakhmatullin, R. R. (2018). Informational basis of the methodology of overcoming opposition to the detection and investigation of crimes. Application of information technology and the problems of digitalization of law: Materials of the XIV International Scientific and Practical Conference "Derzhavinsky Readings", Kazan, Russia, September 12-14, 2018, 1, 260-264.

Ryan, M. R. \& Frater, M. R. (2002). Communications and information systems. Argos Press.

Siegel, L. J. \& Worrall, J. L. (2018). Essentials of criminal justice. Boston: Cengage Learning Publication.

Shubin, O. O. (2010). Analytical assessment of the organization of communal services. Actual problems of economy, 1(103), 175-184.

Tertyshnik, V. M. \& Shcherba, S. P. (2011). A conceptual model of the system of principles of the criminal process of Russia and Ukraine in the light of comparative law. Criminal law Journal, 1, 38-45.

Tonry, M. (2015). Is cross-national and comparative research on the criminal justice system useful? European Journal of Criminology, 12(4), 505-516. https://doi.org/10.1177/1477370815581699 